\title{
Ethnologies
}

\section{For an anthropology of historians}

\section{Van Troi Tran et Patrick-Michel Noël}

Volume 40, numéro 1, 2018

URI : https://id.erudit.org/iderudit/1054312ar

DOI : https://doi.org/10.7202/1054312ar

Aller au sommaire du numéro

Éditeur(s)

Association Canadienne d'Ethnologie et de Folklore

ISSN

1481-5974 (imprimé)

1708-0401 (numérique)

Découvrir la revue

Citer cet article

Tran, V. T. \& Noël, P.-M. (2018). For an anthropology of historians. Ethnologies, 40(1), 49-73. https://doi.org/10.7202/1054312ar

\section{Résumé de l'article}

Le cliché est toujours vivace: les historiens, comme chacun sait, ont tendance à se représenter comme des artisans, qui maîtrisent un savoir-faire pratique acquis patiemment grâce à une expérience pratique de contact avec de documents poussiéreux, et qui montrent un mépris flagrant pour la théorie et les abstractions. Cette image demande un examen plus attentif. Il est intéressant de noter que malgré cette insistance sur une image artisanale de la profession, il existe peu d'enquêtes ethnographiques sur les historiens au travail qui décriraient précisément le savoir artisanal des historiens et les multiples aspects pratiques de la pratique de l'histoire dans différents contextes. L'idée que les historiens font tout bonnement ce qu'ils font semble assez simple, mais comme pour tout « métier ", de la vannerie à la chasse en forêt tropicale, la pratique ne va jamais de soi, que ce soit techniquement ou sociologiquement. Certes, il existe de nombreuses biographies, autobiographies, " égo-histoires ", amorces méthodologiques et essais épistémologiques qui abordent et analysent la problématique de l'historien au travail, mais ces récits réflexifs restent dans une perspective essentiellement " verticale ". S'inspirant des travaux récents en études des sciences et en anthropologie des sciences, nous voudrions proposer dans cet article un programme d'étude " horizontal » des historiens, indépendant de leur propre discours réflexif, et symétrique dans ses explications, de manière à prêter attention aux variétés de leur existence, et à leurs devenirs dans une communauté de pratique.
Ce document est protégé par la loi sur le droit d'auteur. L’utilisation des services d'Érudit (y compris la reproduction) est assujettie à sa politique d'utilisation que vous pouvez consulter en ligne.

https://apropos.erudit.org/fr/usagers/politique-dutilisation/ 


\title{
FOR AN ANTHROPOLOGY OF HISTORIANS
}

\author{
Van Troi Tran \\ Université Laval \\ Patrick-Michel Noël \\ Université de Saint-Boniface
}

\section{The historian's savage mind'}

The historical profession likes to think of itself as a guild; it might more aptly be likened to a tribe. Certainly the rites of passage through which one must pass share more with tribal initiation ceremonies than they do with admission procedures in the craft-guilds. [...] Becoming a historian is a process in which not only a lot of information must be logged in but also a whole set of specific folkways, customs, and mores must be introjected. In large part, this subculturally provided "second nature" consists of a set of restrictions on the kind of questions the novice historian may ask of the past and the ways he may formulate them, rather than a set of procedural rules which tell him how to distinguish between true, false, and anomalous answers to the questions he poses to the documents (White 1973: 36).

Ethnographers are in for a treat: tribes, rites of passage, ceremonies, folkways, customs. The taboos of historians are also addressed by Hayden White in his Tropics of Discourse (1978), and to that list of anthropological tropes, one could easily add the gift economy of peer-reviewing, the oral culture of gossip, urban legends and unwritten traditions within university departments, the clanism of medievalists (Dumoulin 1995), the animistic relationship of historians to their sources, or worse, their fetishism of archival documents, the mysticism of dust and worn parchments (Steedman 2002), and, to some extent, the totemization of prominent figures in the

1. Parts of this paper were presented at the 2015 annual meeting of the Canadian Anthropological Society/Société canadienne d'anthopologie in Quebec City, the 2015 annual meeting of the Canadian Historical Association/Société d'histoire du Canada in Ottawa, and the 2015-2016 seminar "L'écriture de soi des historiens" at the Institut d'histoire du temps présent, Paris. 
discipline. Just as harsh is the tone of Keith Jenkins, who a few decades later furthermore identifies traditional historiography as "a set of guild practices reified by their beneficiaries into tablets of stone" (Jenkins 2003: xix), and he even qualifies the conspicuously unreflexive stance of a certain strand of historians as "intellectually backward" (xvii). Anthropologists rejoice.

Of course, this mobilization of figures from the mid-Century ethnographic record in order to characterize and draw attention to the backwardness of historians is not new in itself. White's characterizations echo seven decades later, perhaps knowingly and albeit on different points, François Simiand's denunciation of "the three idols of the historian's tribe" in 1903, namely, politics, chronology and the individual (republished in Simiand 1960: 83-119), as epitomized by the méthodisme of Langlois and Seignobos. It may very well be that this iconoclastic thrust that runs from the modernist defense of sociological science to the postmodernist deconstruction of historical science relies upon the construction of a mythified savage, iconophiliac Other (see Taussig 1999 on this): the naïve, backward, tribal, clanic historians.

In the context of this article, we are not so much interested in intervening within the well-worn debates between narrativism and hard-nosed empiricism, deconstructionists and reconstructionists, or traditionalists and postmodernists (although these debates would most certainly deserve in themselves a close analysis from the perspective of a sociology of controversies ${ }^{2}$ ). We would rather first point out an interesting discrepancy between this proliferation of anthropological metaphors referring to the "savage" character of traditional ways of doing history, and the lack of actual ethnographies of historians at work that would document the practicalities of their craft across different contexts. If "the number of really sophisticated texts on historical theory, historiography, historical methods and epistemology has multiplied enormously," as Jenkins signals in 2003 (xviii), over a decade later, these concerns do not appear to have gained much traction from the various fields of science studies, from SSK to STS to ANT.

This article could, therefore, be read as both a plea and a program for an anthropology of historians. As we know, anthropologists and ethnographers with training in ethnomethodology, symbolic interactionism, actor-network theory or other strands of cultural analysis have so far developed seminal ethnographic accounts of (among our personal favorites) geneticists in Japan (Houdart 2007), high-energy physicists (Traweek 1988), marine

2. As in, for example, Boltanski (1990), or more specifically Gingras (2014). 
biologists in California (Helmreich 2009), genomics in the Netherlands (Taussig 2009), psychiatrists in Argentina (Lakoff 2005), and countless others. These studies have all been closely attentive to the social, cultural, economic and/or material embeddedness in the unavoidably local production of purportedly universal knowledge. Field observations have thus been made on the most theoretical or abstract of objects such as mathematical reasoning (Lave 1988, Verran 2001), philosophy (Kresse 2007), or Stephen Hawking's thought (Mialet 2012). After all, according to many anthropologists, the "study of knowledge is the sine qua non of social and cultural anthropology" (Marchand 2010: S3), which explains why, since the beginning of the $20^{\text {th }}$ century, anthropology "has always been rather stubbornly concerned with the existential, social and historical intricacies of human knowledge" (Boyer 2007: 28).

Nevertheless, rather surprisingly, there still doesn't seem to be anything resembling a full-fledged ethnography of historians. To be sure, anthropologists have already studied historians, as social actors taking part in wider social controversies or political issues, for example in postsocialist or postcolonial settings. Some of the most prominent figures in the discipline, from Boas to Kroeber to Evans-Pritchard, have also debated the relevance, merits and limits of the "historical method" for social and cultural anthropology. But historians themselves, as professionals, laborers, researchers, artisans, knowledge producers and academic employees, have never been the focus of a systematic ethnographic investigation.

In her book How Professors Think (2010), which analyzes the different cultures of evaluation across academic disciplines in the United States, Michèle Lamont devotes a specific chapter on historians. In this capter, she tags history as "the consensual discipline" insofar as its members tend to crystallize around a "shared agreement" that "what constitutes good historical craftsmanship" is "a sense of "careful archival work," a narrative upon which few historians would probably disagree and with which many anthropologists would probably sympathize. This rhetoric on the value of craftsmanship is indeed also prevalent in current selfdefinitions of anthropology, whether we're talking about Jean Rouch's filmmaking (Henley 2010), the practice of ethnographic writing (Narayan 2012), or ethnography proper (Lave 2001). ${ }^{3}$ But, as we know, when there is a consensual agreement within a community, especially upon such a

3. Not to mention social theory, from Marx to Weber, that is now construed as a "craft" in Richard Swedberg (2014), or Bourdieu's repeated characterizations of sociology as a "craft" learned in "workshops" through "practice" in both his early and later work. 
floating signifier as "craftsmanship," this warrants a deeper ethnographic exploration into what appears to be a black box or an invented tradition. The first section of this article, thus, addresses the implications of the prevalence of this image of the historian as "craftsman," whether evoked in a positive light so as to underline the historian's hardworking ethos, or in a derogatory manner so as to denounce the historian's epistemological naiveté. Our claim is that this opposition between craft and epistemology is not as clear cut as it may appear, especially as one pays attention to the actual production of reflexive accounts by historians (Noël 2012, 2014) or the "self-images of the historical discipline" (Bondì 2011). But moreover, when confronted with anthropological accounts on craft-learning, the content of this widely shared notion of craftsmanship among historians can be reassessed in new productive ways for a better understanding of the apprenticeship of the historian's "craft" and the construction of historical knowledge, more attuned to the ecology of the historian's mind. The other two sections provide arguments for the development of anthropology of the cognitive and bodily aspects of doing history.

\section{Portraits of the historian as craftsman}

One of the most often recurring themes present in the historians' discourse on epistemology is that of its presumed absence in their discipline. Throughout the last decades of the twentieth century, this absence has been both valued in the name of a craftlike conception of history and deplored, especially since the advent of postmodernist reflections on the construction of historical knowledge, to denounce the "matter-of-fact, antitheoretical and antiphilosophical objectivist empiricism" of historians (Novick 1988: 593-594), their "ostensible 'a' or anti-theoretical position" (Jenkins 1997: 1) or the anti-theoretical empiricism, particularly lively among historians. Allan Megill, for example, claims that "the historical profession tends to be quite sharply antitheoretical, or at least untheoretical" (1994: 40). Opposing representations of the historian's ethos have thus mobilized the figure of the craftsman to either promote the savvy practical no-nonsense skillfulness of historians or to denounce their epistemological naïveté.

On the one hand, there is the valued absence of epistemology. Historians have traditionally been portrayed and have represented themselves often as hommes de métier, as (mostly male) artisans mastering a sort of knowhow ${ }^{4}$. Hence a discomfort, if not indifference, felt by historians against

4. On the recurrence of this vocabulary of artisanality, see Antoine Prost (1996: 146). But as Jeremy Popkin points out, this valuing of artisanal knowledge is far from being specific to historians: "In Western traditions of autobiography, stories of the 
epistemological reflections of philosophers who ignore "the problems of the working historian," as Bailyn (1963) once put it. Furthermore, historians consider, according to Barrera, that the " $[\mathrm{t}] \mathrm{rue}$ ' historians are those who produce great historiographical works leaving reflection on history to marginal areas, such as books on "thoughts about history" that some historians write as they reach maturity" (Barrera 2001: 190). They "privilege making history over thinking or talking about it, because [...] its object does not correspond to the task that suits the historian, that is to say, that of telling and analyzing events" (Barrera 2001: 203). In the same vein, Daddow notices that "opting not to reflect on one's craft seems to have a long tradition within the discipline of history" and that the "natural predilection of the historian is to 'do' history rather than think about it" (Daddow 2004: 432), the first operation providing "more career benefits" than the "introspective analysis" characterizing the second operation. This dismissive attitude of historians towards epistemology and philosophy of historiography could be further illustrated in two paradigmatic cases: Pierre Chaunu in France and Geoffrey Elton in Great Britain, who have both occupied dominant positions within their national historiographical traditions, roughly at the same time. In 1960, Chaunu warned against the "dangerous temptations" of epistemology, a "solution of laziness" that speaks for a "sterilizing research." Maybe at most should some prominent figures delve into epistemology in order to keep the other "robust artisans" (our italics) of historical knowledge away from this "morbid Capua" (Chaunu 1978: 10). Elton argued, as is well known, that a "philosophic concern with [...] the nature of historical thought only hinders the practice of history", and if "every new number of History and Theory is liable to contain yet another article struggling to give history a philosophical basis [...] they do not, I fear, advance the writing of history" (Elton 1967: 70). In short, from their own experience, these historians value the absence of epistemology because they think it compromises the very practice of their craft.

This opposing posture, developed in the wake of postmodernism and the perception of a disciplinary crisis (Noiriel 2005) in the last quarter of the 20th century, has symmetrically crystallized its arguments around this artisanal conception of history, in order to criticize its unwarranted self-

discovery or development of a vocation occupy an important place. Recounting how they acquired their professional skills and came to be recognized for their abilities allowed preindustrial artisan-autobiographers, such as the Frenchmen Jacques Ménétra and Agricol Perdiguier, to convince readers that they were autonomous and productive individuals whose lives deserved recording" (Popkin 2005: 120). 
confidence associated with a wholesale rejection of theory and epistemology. LaCapra, who has arguably been the historian who has most denounced the absence of an epistemological culture among historians, claims that historians practice an "archival fetichism," and display confidence in their "tacit craftlike procedure" while resisting the appeal of "theory" (LaCapra 1980, 1989). By questioning the modern foundations of historical knowledge - the very possibility of a true and objective knowledge of the past ${ }^{5}$ - the postmodern challenge has indeed destabilized the self-images of the discipline. Daddow has, thus, noted that it took the postmodern challenge for historians to get rid of what he calls the "ideology of apathy": since the disciplinarization of their practice in the 19th century, historians have continually displayed a "reticence [...] about reflecting at any length on the theoretical and philosophical underpinnings of their craft" (Daddow 2004: 432).

In response to the postmodern challenge, several historians have, therefore, stressed the necessity of an epistemological reflection in order to defend the boundaries of their discipline and to legitimize its modern founding aspiration to produce a true knowledge of the past. Beyond the different positions historians took on the implications of postmodernism for their discipline - for a great part gathered in readers (Jenkins 1997, Domanska 1998) and ranging from an unqualified support to a hostile rejection, including a more nuanced appropriation noting that postmodernism has at least the merit of encouraging historians to greater reflexivity and reminding them of the ethical imperative at the core of their intellectual enterprise - it is the very status of epistemology within the discipline of history that has changed (Noël, 2018). One of the most tangible signs of this shift has been the creation of a journal, Rethinking History, adhering explicitly to postmodernism and devoting itself largely to the exploration of issues concerning the theory of the historical practice. By promoting a self-reflexive historical knowledge, the journal presents itself as a forum where historians can discuss its "epistemological status": "What is the nature of historical evidence and what function does it perform? What is the role of the historian and of the construction of explanatory frameworks in historical understanding? How significant to our historical understanding is its narrative form?" (Munslow 1997: 3).

From our perspective, however, we believe that these debates could

5. More generally, Bruno Latour, referring to Baudrillard, has remarked that "postmodernism rejects all empirical work as illusory and deceptively scientific" (1993: 46). 
be framed otherwise. It appears to us that this opposition curiously mirrors Levi-Strauss' famous distinction (1966) between the "domesticated" (abstract, scientific, conceptual) mind of the engineer and the "wild" (practical, perceptual) mind of the bricoleur, the latter being (in LeviStrauss' work) revalued for its richness and adaptability over the former (Keck 2004). A heuristic shortcoming of the spontaneous anthropology of historians gathered around the notion of craftsmanship is that, as Goody has convincingly argued in his criticism of Levi-Strauss (Goody 1977), it tends to eventually underplay both the developmental aspect of "apprenticeship" and the transformative role of the "technologies of the intellect" such as, above all, writing. ${ }^{6}$ If the traditional anti-epistemological stance builds on the conviction that the good historian, "shows that he knows by what he does" (Hexter 1971: 20), this ultimately begs the ethnographic question of what is it that historians do and how this purportedly practical and nondiscursive knowledge can be described without resorting to textbook clichés about "careful archival work," not any less abstract than epistemological circumlocutions on the nature of historiographic writing.

It would be appropriate to first answer this question by pointing out that historians have already been very prolix about their craft. Recent anthologies from Carbonell and Walch (1994), Delacroix, Dosse and Garcia (2003), Jenkins and Munslow (2004), or Bédard and Goyette (2006) show that since the institutional establishment of their discipline in the 19th century, historians have always, in conjunction with their empirical research, produced theoretical reflections on the nature of their craft - albeit to a lesser extent and almost never in a specialized manner. ${ }^{\text {? }}$ These anthologies give empirical proof to dispute what Zammito considers to be a "long-standing view that historians are incapable of theoretical self-reflection" and the related conception of a discipline composed of "inveterately 'naïve' members" (2004: 156). They debunk the myth of the historian as a hopeless empiricist refusing epistemological introspection and attest that their discipline, to quote Quebec historian Alfred Dubuc, "has a capacity for epistemological interrogations" by which it constantly re-assesses "its foundations, its postulates and the quality of the knowledge it attains" (quoted in Bédard and Goyette 2006: 180). The epistemological, "indigenous" (Noiriel 2005) reflections of historians have obviously a practical if not spontaneous dimension that sharply contrasts with the abstract, formalized and systematical ruminations of philosophers and

6. On recent efforts to overcome narrativism, see Domanska (2010).

7. What anthropologists would call, in another context, "knowledge." 
epistemologists. Nonetheless, through this meta-discourse, historians have defined and justified their knowledge, and they have produced and still produce explicit representations of their craft and their profession in order to give it a shape, a form, an identity. This surprisingly massive editorial production forcefully shows that historians are certainly far from being the cultural dopes of Humanities faculties amongst institutions of higher education.

But these emic descriptions also have their obvious limitations as they tend to remain essentially normative, impressionistic, or both. Besides their idiosyncratic nature, they often stop short of providing "satisfying explanation (or approximations) of how learning, knowing, and practice actually occur, take shape, and continually transform with situated bodies and minds" (Marchand 2010: S3). To paraphrase some of the seminal works in the anthropology of science, in the case of historians, we seem to lack a description of their scientific practice that would be independent of their own reflexive discourse and symmetric in its explanations (Latour and Woolgar 1979), and it would be interesting to provide an account of how historians (instead of high-energy physicists) "see their own world: how they have forged a research community for themselves, how they turn novices into [historians] and how their community works to produce knowledge." (Traweek 1988: 1) So while we may agree with Jenkins that the tautological rhetoric that affirms that historians just do what they do might be questionable it itself, in only for not being attentive to the intersubjective dimension of science. It does not follow, however, that these "job descriptions" are necessarily self-evident, or at least any more self-evident than the description of any "craft" that one might find within the anthropological literature.

It is true that this figure of the craftsman seems to unavoidably generate images d'Épinal of a patient, hardworking, no-nonsense, most probably male historian. Or, not unlike the valuation processes of artisanal commodities, it would not be too far-fetched to claim that this insistence on the artisanality of historical knowledge acts as the equivalent of a stamp of cultural authenticity for the promotion of scientific objects exposed on the marketplace of academic publications. But from an ethnographic perspective, this notion of "craftsmanship" could be unpacked differently in productive ways. It could be used, not as an explanatory concept, but as a "sensitizing concept" that draws attention to the spatiotemporal singularities and the historical and cultural specificities of learning processes at work, or, to put it bluntly, to the embodied dimension of knowledge 
production in times of neoliberal standardization. "Craft" as a notion does not explain much, but it is a black box that fertilizes an ecology of additional images (fabric, workshop, toolbox, apprenticeship, know-how) that have the potential to shed light on the multilinear processes along which the actual skills of practitioners come to maturity, through practice, repetition, adaptation and failure.

\section{How are historians reflexive?}

Craft and reflexivity, then, should not be seen as opposites.

We all have in mind Péguy's quip that historians "don't want to write a history of historians" as if "doctors didn't want to fall ill and die," as quoted in the epigraph of Bourdieu's Homo Academicus (1988: 1). Historians are purportedly unwilling to properly historicize their own practice and the social construction of their concepts and objects, or, to speak in Bourdieu's language, to objectify the subject of objectification. This is something on which historians of bourdieusian allegiance (Charle 2013, Bourdieu and Chartier 2015) seem to wholeheartedly agree: whereas some figures find delight in autobiographical self-examinations and "ego-histories," these navel gazing exercises refrain from a critical examination of the social and institutional embeddedness of their trajectories that allow for the production of specific conditions of possibility of practice, by settling in the comforting illusion of scholasticism (Bourdieu 2004).

There is much to agree with in Bourdieu's criticism of the scholastic pitfalls of historiography and the artificial linearity of the "biographical illusion" and its individualistic assumptions. After all, what is historiography if not an anti-sociology, a victor's history of great figures, famous professors, seminal works and successful research programs? Although they have considerably sociologized themselves in recent years and freed themselves from this brand of whiggism (den Boer 1998; Poirrier 2004; Noël 2008), histories of historians are not always historicized properly and fail to provide a comprehensive account of the social forces and the missing masses involved in the collective and institutional fabric of historical knowledge. It would, moreover, be relevant to point out that, whereas historians tend to emphasize spatiotemporal continuities on their objects, they are conversely inclined to insist on historiographical discontinuities in order to underline the originality of their own work. On this page, they are not unlike anthropologists, keen to stress the shift from travel writing to ethnography as a founding moment in the discipline, thus buffing out the 
genealogic connections between nineteenth century missionary writings and twentieth century ethnography (Debaene 2014). The narratives of epistemological breaks are often more performative than descriptive, as the ritualistic wholesale rejection of older paradigms may itself provide a lever for the promotion of new sensitizing concepts and perspectives for the study of the past.

This representation of a generalized lack of reflexivity among historians - coextensive with the figure of the historian as craftsman - has to be questioned, precisely for the reason that its normative underpinnings fail to account empirically for the multiplicity of cognitive operations involved in the construction of historical knowledge (Koposov 2009), the bits and pieces of reflexive and epistemological ruminations inherent in the practice of historical investigations (Noël 2014), and their diversity across cultural and historical situations. Or, in other words, their "craftiness." Furthermore, it could be argued that an effect of postmodernism was to make visible the actual mingling and entanglement of theory and practice. According to LaCapra, one of the beneficial effects of the perception of a disciplinary crisis such as the one caused by postmodernism, was "the pressure it places upon practioners [...] to be more articulate about what they are doing and why they are doing it" (LaCapra 1980: 245). Munslow further notes in the first editorial of Rethinking History that the "anxiety" among historians generated by the perception of a disciplinary crisis had a "practical result": the production of texts addressing directly or indirectly "the epistemological foundations of the historical project" (Munslow 1997: 4).

Reflexivity should hence not be treated as a politically and scientifically liberating epistemic virtue, as Bourdieu seems to imply, but as an irreducible dimension of the historian's craft in action, a dimension that has yet to be unwrapped, examined and historicized. As feminist scholars have suggested, the universalistic tenets of a critical reflexivity "from nowhere" that would ultimately aim at an exhaustive social understanding of what constitutes the researcher, the researched and the research context, are bound to empirical failure, infinite regress, or both (Rose 1997). The drawback of this definition of reflexivity, tagged as "transparent" by Rose, is that it tends to underplay the hesitations, uncertainties and contradictions inherent in the conduct of intellectual work. And these uncertainties arise precisely because actors are reflexive when they participate in the production and reproduction of their social world. In order to carry on with their everyday activities, they constantly have to produce states of affairs, singly and together, retrospectively and prospectively (Lynch 2000) 
and these states of affairs, taken indiscriminately, can be empowering or undermining, liberating or self-defeating. An ethnography of the historian's craft in action would, thereby, explore the modes of iteration of these reflexive practices and the role they play in the production of historical knowledge, particularly when they entail a reference to, or a criticism of, a historiographical canon or a disciplinary tradition. As descriptions of historians in action cannot be deduced or reduced to bullet point lists of methodological precepts, Foucaldian disciplines, or inherited traditions, an attention to the indetermination of their science in the making allows not only for a keener empirical sensitivity to what historians do as social actors, but it also to provide a better intelligibility of scientific practices in the present.

We can illustrate this with an example from the context of our research in the anthropology of historians in Quebec. Here, when asked to provide narratives of their careers as historians, a form of interiorized reflexivity was enacted specifically in their accounts in the almost automatic, not to say ritualistic, expressions of discomfort towards the genres of biography, autobiography and the idea of indulging in "ego-history", while our project was never presented or advertised as an exercise in gathering "egohistories" - because what Pierre Nora did in his collection was precisely what we wanted to avoid: life histories of important figures. The informants themselves were for the most part eager to participate, but not without a number of caveats. This is not unlike, despite substantial differences in their respective projects, Levi-Strauss' professed loathing of travel narratives in the first sentences of Tristes Tropiques, Bourdieu's defiance of the conventions and illusions of autobiography in his Sketch for a self-analysis (2008) or, for that matter, most of the texts collected by Pierre Nora in the Essais d'égohistoire (1987): all could be somewhat maliciously described as biographies in denial. Expressions heard such as: "the happenstance historian," "the accidental historian," and repeated evocations of randomness and chance in their choice to become historian, could be, from a normative standpoint, interpreted as failure to properly historicize oneself by invoking mysterious factors such as accidents, happenstance or unknown conjectures. But passing out grades to historians is not our job. These iterations expressed not only a trained attention to the actual role of uncontrollable circumstances or institutional contingencies in the construction of a professional identity, but also what could be interpreted as both an ingrained attitude of defiance towards unreflexive and linear biographical narratives and a nurtured awareness of the limitations of historical knowledge, especially when one is talking about oneself, as well as to the importance of the immediate and 
multilayered contexts for the social production of professional academics as experts and knowledge-makers.

Anthropologists have long paid close attention to this local entanglement of knowledge and of how "knowing" is always "bound up one way or another with the world" since "a person does not leave their environment to know, even when she is dealing with the most abstract of propositions" (Harris 2007: 1). This is very well highlighted, for example, in the work of James C. Scott who addresses the discrepancies between abstract, textual knowledge and practical, non-textual knowledge, knowledge that is "locally superior" and only acquired through experience such as the pilot's skill to navigate through currents, changing wave patterns, shifting sandbars and reefs (Scott 1998: 316), or, in another well-known ethnographic example, Descola's Achuar hunters' abilities that only come to maturation over a decade after their familiarization with the taxonomies of the Amazon forest, as the execution of tasks has been absorbed as a series of automatic actions rather than as a list of the operations that need to be performed (Descola 2014).

At the periphery of anthropology, scholars theoretically at odds, such as Bourdieu and Latour, both offer attempts to rematerialize and localize the practice of science in order to assert the specificity and the historicity of scientific practices. Bourdieu develops his criticism of the fictions of the scholastic vision that focuses on "a knowing consciousness acting in accordance with the explicit norms of logic and experimental method," and thereby blinds us to the tacit, corporeal dimension on the practical sense involved in the fostering of a scientific ethos (Bourdieu 2004). Latour, for his part, defetishizes the scientist's mind, spirit or brain and attempts to undermine what he deems as modern understandings of Science, by asserting the networked, distributed and hybrid composition of science in the making (Latour 1987). And while their views on the value of "reflexivity" are diametrically opposed, ${ }^{8}$ both acknowledge the importance of precognitive habits in research, as Bourdieu would like to foster a "reflex of reflexivity" among scientists, and Latour claims that scientific training shall be "repetitive" and "boring" for the acquisition of "know-how" and "automatisms" (Latour 2001: 94).

8. Whereas Bourdieu seems to value his brand of reflexivity as a universalizable epistemic virtue, and Latour claims that "Most of what social scientists call 'reflexivity' is just a way of asking totally irrelevant questions to people who ask other questions for which the analyst does not have the slightest answer" (Latour 2005: 151). 
As Ricoeur seems to suggest in his criticism of White, these practicalities of historical writing and research, what would fall under the rubric of the "the scientific procedures of historical knowledge," the "documentary moment" and the "referential moment" (Ricoeur 2004: 252-253), that separate history from fiction are the crucial limitations from analyses of historical discourse bracketed in a narrativist framework. But, quite unsurprisingly, and this is not a criticism per se, Ricoeur's account is poor in sociological and ethnographic detail. What the aforementioned authors emphasize in their own ways is the importance of treating reflexivity as a situated practice. In a context of a delocalization of academic work through a bureaucratization of research that leads to a proliferation of "grey" reflexive discourses, such as audits, reports and evaluations (Strathern 2000), it might be relevant, following the aforementioned authors to treat reflexivity locally. In the political struggles for academic relevance, we might be missing an anthropology of the historians' reflexivity as a situated practice, a mode of positionality in the production of knowledge, an operation of performing a specific and differential timescape, a body technique of "unhastening" as Pels (2003) puts it, which enables the construction of a contingent space of autonomization that precisely allows for the practice of history.

\section{The historian's two bodies}

In much writing on apprenticeship, there remains at least a residual assumption that the core of what the apprentices learn is their craft. While that may be the ideology and the ostensible intention, it is commonly not what actually happens. Even when apprentices fail to learn much about the craft, however, they may acquire a good deal of practical social knowledge. Indeed, it may happen that the sheer frustration of apprenticeship prepares them well for a sometimes relentlessly agonistic social milieu (Herzfeld 2004: 52-53).

In The Writing of History, Michel de Certeau, delving into the arcana of the "historiographical operation," asks a number of unanswered questions about how historians work:

What do historians really fabricate when they 'make history'? What are they 'working on'? What do they produce? Interrupting their erudite perambulations around the rooms of the National Archives, for a moment they detach themselves from the monumental studies that will place them among their peers, and walking out into the street, they ask, 'What in God's name is this business? What about the bizarre relation I am keeping with current society and, through the intermediary of my technical activities, with death?' (de Certeau 1992: 56). 
As some of the most hard-nosed historians tend to admit, the chain of operations ${ }^{9}$ that leads from the selection of archive series to the classification of index cards to the production of drafted books or scholarly articles gets itself done in an "insensible" manner (Farge 2013). In his review of Arlette Farge's Allure of the Archives, Robert Darnton uses the more material terms of "maceration" and "concoction" to describe the peculiarity (dare we say alchemy?) of the cognitive operations involved in the construction of history that transforms dusty archives into journal articles or history books. The chaotic crowd of facts and documents has, thus, to "macerate" in the historians' mind before they come to make sense in a larger frame of analysis. ${ }^{10}$ As Darnton admits, it "sounds like hocus pocus" (2014: 53).

At first glance, these testimonies on the cognitive practicalities of historical research are in tune with Michael Polanyi's proposition that the human body contains unexplored reservoirs of tacit knowledge (Polanyi 1983), a body of know-how that is continually activated but never articulated (Biagioli 2005). ${ }^{11}$ Indeed, even the most talented of historians may find some difficulty in describing what the actual process of transfiguring dusty archives into academic publications. But the notion that the historian's craft or know-how can never really be captured, if only through enigmatic metaphors and oblique images, such as "concoction" or "maceration," may well be a very convenient narrative sustained in order to secure a monopoly of discourse over the critical assessment of one's own knowledge (Ingold 2013: 109). And is it really the case? When pressed to describe their experience with clerks at archive centers, the development of research questions, the constitution of their databases, the elaboration of modes of classification, historians are more than often very eager to discuss the practicalities of their craft and the tricks of their trade. ${ }^{12}$ This is not unlike traditional apprenticeship. Craftspeople "'silently' acquire their myriad of skills on the job", but the possession and performance of these skills also "become inextricably tied to their emerging social and professional identities" (Marchand 2008: 248). Post hoc accounts of historians writing about their work are thus relevant, not just for their ethnographic content of anecdotes with old dusty documents in regional

9. Although that notion may well indeed be too linear.

10. We may indeed question this symbolic imagery of dirt and pollution that seems to pervade historians' accounts of their sensuous encounters with archives (Steedman 2002).

11. See also Sibum (1995) and more recently Waquet (2015) who explore ways to address the skills and the bodies in action of scientists.

12. See for example, Guy Thuillier's two recent massive essays $(2013,2015)$ totaling over 1500 pages, and both tellingly subtitled "Introduction to the historian's craft." 
archive centers or their reflexive musings on the object or writing of history, but also for their construction of a public image of the profession through their choices and omissions in defining what doing history as a historian involves ${ }^{13}$.

For example, when reflecting on the nature of the knowledge they produce, historians have largely overlooked the fact that writing is not just a technology of the intellect (Goody 1977) but also a Maussian "technique of the body" (Ingold 2000: 403), involving gestures, habits, ecologies and technical adaptations that cannot be sundered from cognitive operations, as minds are not disembodied logical reasoning devices (Hutchins 1995, Clark 1997) ${ }^{14}$. This is another version of the craft and such an interrogation into the fabric of history and historians (treating both as coextensive) follows anthropologies of apprenticeship that highlight how skill is not transmitted through formulae that are translatable and mutable from one context to another, but "through practical, 'hands-on' experience" (Ingold 2000: 291): a situated knowledge that can only be uncovered by way of a situated ethnography. Not only are careful archival research, crafting databases and writing scholarly articles not usually learnt in the classroom, neither are the "tools" mobilized easily passed on from one historian to another, despite the amount of standardization involved with the digitization of scholarly activities in recent years.

But crafting oneself as a historian goes even further than that. What de Certeau's account actually draws our attention to is, more precisely, how historians experience the apparent discrepancy between the messiness of their "science in the making" and the assertiveness of their "ready-made science" (Latour 1987), which both involve differential timescapes of practice. To paraphrase Kantorowicz, there seems to be a distinction not

13. It is telling that historiographical and epistemological essays on the writing of history (such as Veyne 2004) have carefully examined textual operations, falling into what Noiriel calls "activités de savoir," but not the "activités de mémoire," related to the social diffusion of historical knowledge, and the "activités de pouvoir" such as peer evaluation or recruitment in the profession (Noiriel 2005: 12). To avoid irresolvable philosophical quarrels into which the "historiens-épistémologues" sink, Noiriel implores historians to reflect on their discipline as historians (our italics), that is, with the tools of their own know-how (Noiriel 2005: 152). It is with these tools, as Zammito notes, that one can understand that the practice of history consists of "the intricate day-to-day labors of peer review, manuscript submissions, grant proposals, publications, graduate student preparation and hiring, career promotions" (Zammito 2004: 303).

14. See also Ingold's (2011) criticism of Sperber's epidemiology of representations (1996). 
between a natural and a sacred body as in Kantorowicz's study, but more modestly between the private and public bodies of the historian and the different ecologies of practice through which a historian has to navigate between the private and public aspects of research. When Bloch, in The Historian's Craft, expresses his hesitations about the exposition of the shillyshallying that actually takes place within the historian's workshop, behind the closed doors of reading rooms when no one is watching, he evokes "the curious modesty which, as soon as we are outside the study, seems to forbid us to expose the honest groping of our methods before a profane public" (Bloch 1953: 72). But it is perhaps not so curious, considering the importance of "public secrecies" in the cementing of collective identities (Taussig 1999): the limits, frailties and uncertainties of scientific investigations of the past that historians are not only fully aware of, but upon which they develop a sense of shared professional belonging.

Bloch's and de Certeau's hesitations, thus, unwittingly invite us to explore what might be called the "cultural intimacy" of scientific practice, that is: "the zone of internal knowledge whereby members of a society recognize each other through their flaws and foibles rather than through their idealized typicality." 15 From his experience with the study of artisans in Crete, Herzfeld has come to the surprising conclusion that apprentices "often learn despite the fact that their masters, far from teaching them, often seem to discourage them quite deliberately from learning anything at all" (Herzfeld 2004: 51). What they learn from their masters is less how to practice a craft, handle the tools and work with materials, than how to behave like an artisan. ${ }^{16}$ This is something that quite a few current History graduate students may find relatable, and it actually echoes Eskildsen's account of Leopold von Ranke's famous seminars in Berlin, both formalized around a set of rigid principles and regulations, and ruled by a number of unwritten rituals and informal rules in the selection and discipline of pupils (Eskildsen 2007). The production of public identities unavoidably entails the creation of backstage activities and relationships and the task of an anthropology of historians would then be precisely to explore with ethnographic minutiae the details, logics and contradictions

15. "By 'cultural intimacy' I do not simply mean close acquaintance with a culture but, rather, the zone of internal knowledge whereby members of a society recognize each other through their flaws and foibles rather than through their idealized typicality as heroic representatives of the nation. I call this mutuality a 'fellowship of the flawed"' (Herzfeld 2009: 133).

16. As Lave has shown is her study of tailors in Nigeria, by confining the study of apprenticeship to task-knowledgeability, one might precisely miss what it means to "become a tailor." See Lave (2011: 65-90). 
that emerge within this zone. The "good way to do history" through the slow maceration of historical materials is, thereby, actually coextensive with learning the good way to become a historian within a professional community of practice. Artisans are not just learning techniques, they are "forming their own selves" (Mills 1959: 216), they are crafting their own crafty personas. Historians learn to become acquainted with the unwritten norms of their peculiar academic culture, and interiorize "that part of a cultural identity that insiders do not want outsiders to get to know yet that those same insiders recognize as providing them with a comfort zone of guiltily non-normative carryings-on" (Herzfeld 2013: 491).

Published accounts from historians relating their experience with archives and with "the embodied experiences of the physical, emotional, intellectual, and political encounters between the scholar and the archive itself" (Burton 2005: 9) do provide very rich descriptions of how the material setting of historical research modulates how knowledge is produced and performed. Some will even insist on bodies, gestures and fatigue of historians working in archives, and how they admit cutting corners after a whole afternoon of sifting through microforms and develop impostor syndrome. But as useful and compelling as these narratives are for a material understanding of the peculiarities of the historian's craft in practice, they are not replaceable with a more horizontal investigation into what historians do that would provide broader framings for the understanding of the practicalities of the historian's craft. Two telling signs are the tendency to treat research in archives as a "set-apart" context (as best highlighted in the de Certeau quote above) and the glaring lack of consideration among these accounts for the intersubjective dimension of scientific work, from peerreviews to department meetings. The idea of participant observation that, since Malinowski, constitutes the methodological credo in anthropology relies precisely on the notion that the cultural life of practitioners is always much more complex than what is presented at first glance, in public or in written documents. From this derives the importance of fieldwork as a social and corporeal experience where the ethnographer can deconstruct the body (carnal and social) as a cultural, biographical construction through a lived and interactive encounter with others' cultural construction and bodily experience.

\section{Conclusion}

The anthropology of historians that we have outlined in this text could be construed as an endeavor to push further the well-engaged movement 
towards a better understanding of the discipline of history in two directions.

First, it is part of a larger project already set in motion mostly up until now by certain philosophers of history consisting of naturalizing the epistemology of history, to use Quinean terms. Since the 1990s, but more so since the 2000s, against the excess of prescriptive positivism à la Hempel considering history as a science manquée and of the different strands of postmodern aesthetic narrativism reducing history to a text, philosophers have argued that the task of the epistemology of history is "to elucidate the practice of history" (Lorenz 1994, see also Tucker 2004). History as a form of knowledge is conceptualized less as a finished product "than as a production process" (Paul 2011: 3), as a performance involving "virtues, skills and desires" (Paul 2014). An anthropology of historians would be a promising way to understand history in such a way, that is, without dispensing with a study of the experiences of those who practice it in an intersubjective community, the historical discipline.

Second, as Dominic Boyer argues, “As 'knowledge workers' of a particular sort operating in a 'knowledge economy' it is therefore important to remain mindful that the problem of knowledge for anthropologists and other academics cannot be treated simply as a matter of conceptual interest. Rather, it is important to be clear that our own contemporary engagement with 'knowledge' is also always entangled with the economies of expertise (both external and internal to universities) that refract our professional identities, activities, and productivity." (Boyer 2005a: 147) The idea that knowledge can be transferable smoothly from one context to another, perhaps best exemplified in the various incarnations of the neoliberalization of universities and the rise of "audit cultures" and "evaluation fevers," has to be documented in its effects on both the self-images and the practice of the discipline. Boyer again claims that: "[i]ntellectual professionalism [...] is [...] itself responsible for cultivating a phenomenological awareness of mental distinction into an 'ontological' divide between mind and body. [When] [o]nce defined in opposition to mind, the body of the professional intellectual is treated as an efficient yet passive mechanism for energizing mental activity" (Boyer 2005b: 244). An anthropology of historians would certainly be a fruitful way of addressing the situated practicalities of neoliberalization, as Ong puts it, the little things and devices that make it work across different contexts (Ong 2006). But it would also contribute to undermining and deflating overarching accounts on the production of knowledge, as it would reassert the importance of the historian's craftsmanship in the current political struggles for disciplinary relevance, 
not as a spontaneous unreflexive wisdom that allows for an unearned contempt towards anything theoretical, but as local know-how, practically relatable, but never thoroughly translatable across time and space. 


\section{References}

Bailyn, Bernard. 1963. "The problems of the working historian.” In Sidney Hook (ed.), Philosophy and History: 92-101. New York: New York University Press.

Barrera, José Carlos Bermejo. 2001. "Making history, talking about history." History and Theory 40(2): 190-205.

Bédard, Éric and Julien Goyette (eds.). 2006. Paroles d'historiens: Anthologie des réflexions sur l'histoire au Québec. Montréal, Presses de l'Université de Montréal.

Biagioli, Mario. 1995. "Tacit Knowledge, Courtliness, and the Scientist's Body." In Susan Leigh Foster (ed.), Choreographing History: 69-81. Bloomington: Indiana University Press.

Bloch, Marc. 1953. The Historian's Craft. London: Vintage.

Boltanski, Luc. 1990. L'amour et la justice comme compétences. Paris: Métaillé. Bondì, Davide. 2011. "What Philosophers of History Can Do with the Self-Images of the Historical Discipline." Storia della Storiografia 59. 60: $150-223$.

Bourdieu, Pierre. 1988. Homo Academicus. Stanford: Stanford University Press.

- 2004. Science of Science and Reflexivity. Chicago: University of Chicago Press.

- 2008. Sketch for a Self-Analysis. Chicago: University of Chicago Press.

Bourdieu, Pierre and Roger Chartier. 2015. The Sociologist and the Historian. London: Polity.

Boyer, Dominic. 2005a. "Visiting Knowledge in Anthropology: An Introduction." Ethnos 70(2): 141-148.

- 2005b. "The Corporeality of Expertise." Ethnos 70(2): 243-266.

- 2007. "Of Dialectical Germans and Dialectical Ethnographers: Notes from an Engagement with Philosophy." In Mark Harris (ed.), Ways of Knowing: Anthropolgical Approaches to Crafting Experience and Knowledge: 27-41. New York: Berghahn.

Burton, Antoinette. 2005. "Introduction: Archive Fever, Archive Stories." In Antoinette Burton (ed.), Archive Stories: Facts, Fictions, and the Writing of History: 1-24. Durham: Duke University Press.

Carbonell, Charles Olivier and Jean Walch (eds.). 1994. Les sciences historiques de l'Antiquité à nos jours. Paris: Larousse.

Charle, Christophe. 2013. Homo historicus. Réflexions sur l'histoire, les historiens et les sciences sociales. Paris, Armand Colin.

Chaunu, Pierre. 1978. Histoire quantitative, histoire sérielle. Paris: EHESS- 


\section{Armand Colin.}

Clark, Andy. 1997. Being There: Putting Brain, Body, and World Together Again. Cambridge: MIT Press.

Daddow, Oliver J. 2004. "The Ideology of Apathy: Historians and Postmodernism." Rethinking History 8(3): 417-437.

Darnton, Robert. 2014. "The Good Way to Do History." New York Review of Books January 9: 52-55.

Debaene, Vincent. 2014. Far Afield. French Anthropology between Science and Literature. Chicago, University of Chicago Press.

de Certeau, Michel. 1992. The Writing of History. New York: Columbia University Press.

Delacroix, Christian, François Dosse and Patrick Garcia (eds.), Histoire et historiens en France depuis 1945. Paris: Adpf-Éditions.

den Boer, Pim. 1998. History as a profession. The study of history in France 1818-1914. Princeton, Princeton University Press.

Descola, Philippe. 2014. Beyond Nature and Culture. Chicago: University of Chicago Press.

Domanska, Ewa. 1998. Encounters: Philosophy of History after Postmodernism. Stanford, Stanford University Press.

2010. "Beyond Anthropocentrism in Historical Studies." Historein 10: $118-130$.

Dumoulin, Olivier. 1995. "La tribu des médiévistes," Genèses 21(1): 120 133.

Elton, George. 1967. The Practice of History. London: Fontana Books.

Eskildsen, K.R. 2007. "Leopold von Ranke, la passion de la critique et le séminaire d'histoire." In Christian Jacob (ed.), Lieux de savoir 1: Communautés et institutions: 462-482. Paris : Albin Michel.

Farge, Arlette. 2013. The Allure of the Archives. New Haven, Yale University Press.

Gingras, Yves. 2014. Controverses: Accords et désaccords en sciences humaines et sociales. Paris: CNRS Éditions.

Goody, Jack. 1977. The Domestication of the Savage Mind. Cambridge: Cambridge University Press.

Harris, Mark. 2007. "Introduction: 'Ways of Knowing'." In Mark Harris (ed.), Ways of Knowing: Anthropolgical Approaches to Crafting Experience and Knowledge: 1-24. New York: Berghahn.

Helmreich, Stefan. 2009. Alien Ocean: Anthropological Voyages in Microbial Seas. Berkeley, University of California Press.

Henley, Paul. 2010. The Adventure of the Real: Jean Rouch and the Craft of Ethnographic Cinema. Chicago: University of Chicago Press. 
Herzfeld, Michael. 2004. The Body Impolitic: Artisans and Artifice in the Global Hierarchy of Value. Chicago: University of Chicago Press.

2009. "The cultural politics of gesture: Reflections on the embodiment of ethnographic practice." Ethnography 10(2): 131-152.

- 2013. "The European Crisis and Cultural Intimacy," Studies in Ethnicity and nationalism 13(3): 491-497.

Hexter, Jack. 1971. Doing History. Bloomington: Indiana University Press. Houdart, Sophie. 2007. La cour des miracles: ethnologie d'un laboratoire japonais. Paris, CNRS Éditions.

Hutchins, Edwin. 1995. Cognition in the Wild. Cambridge, MIT Press. Ingold, Tim. 2000. The Perception of the Environment. Essays on Livelihood, Dwelling and Skill. London: Routledge.

2001. "From the Transmission of Representations to the Education of Attention." In Harvey Whitehouse (ed.) The Debated Mind: 113153. Oxford, Berg.

- 2013. Making: Anthropology, Archaeology, Art and Architecture. London: Routledge.

Jenkins, Keith. 1997. “On Being Open about our Closures.” In Keith Jenkins (ed.), The Postmodern History Reader: 1-25. London: Routledge. 2003. Refiguring History: New Thoughts on an Old Discipline. London: Routledge.

Jenkins, Keith and Alun Munslow (eds.). 2004. The Nature of History Reader. London: Routledge.

Koposov, Nikolay. 2009. De l'imagination historique. Paris, Éditions de l'EHESS.

Keck, Frédéric. 2004. Levi-Strauss et la pensée sauvage. Paris: PUF. Kresse, Kai. 2007. Philosophising in Mombasa: knowledge, Islam and intellectual practice on the Swahili coast. Edinburgh: Edinburgh University Press.

La Barbera, Serge. 2008. Un sentiment d'imposture. Paris: Allia. 2009. Microfilm 2mi354. Paris, Allia.

LaCapra, Dominick. 1980. "Rethinking Intellectual History and Reading Texts." History and Theory 19(3): 245-276. 1989. Soundings in Critical Theory. Ithaca: Cornell University Press.

Lamont, Michele. 2010. How Professors Think. Cambridge, Harvard University Press.

Lakoff, Andrew. 2005. Pharmaceutical Reason: Knowledge and Value in Global Psychiatry. Cambridge, Cambridge University Press.

Latour, Bruno. 1987. Science in Action: How to Follow Scientists and Engineers through Society. Cambridge: Harvard University Press.

- 1993 We Have Never Been Modern. Cambridge: 
Harvard University Press.

- Le métier de chercheur: regard d'un anthropologue. Paris: INRA éditions.

Reassembling the Social: An Introduction to Actor-Network Theory.

Oxford: Oxford University Press.

Latour, Bruno and Steven Woolgar. 1979. Laboratory Life: The Construction of Scientific Facts. Beverly Hills: Sage.

Lave, Jean. 1988. Cognition in Practice: Mind, Mathematics and Culture in Everyday Life. Cambridge: Cambridge University Press.

Apprenticeship in Critical Ethnographic Practice. Chicago, University of Chicago Press.

Levi-Strauss, Claude. 1966. The Savage Mind. Chicago: University of Chicago Press.

Lorenz, Chris. 1994. "Historical Knowledge and Historical Reality: a Plea for 'Internal Realism'." History and Theory 33(3): 297-327.

Lynch, Michael. 2000. "Against Reflexivity as an Academic Virtue and Source of Privileged Knowledge." Theory, Culture EF Society 17(3): 26-54.

Marchand, Trevor H.J. 2008. "Muscles, morals and mind: Craft apprenticeship and the formation of person." British Journal of Educational Studies 56(3): 245-271.

2010. "Making knowledge: explorations of the indissoluble relation between minds, bodies, and environment." Journal of the Royal Anthropological Institute 16(supplement S1): S1-S21.

Megill, Alan. 1994. “Jörn Rüsen's Theory of Historiography between Modernism and Rhetoric of Inquiry." History and Theory 33(1): 39-60.

Mialet, Helene. 2012. Hawking Incorporated: Stephen Hawking and the Anthropology of the Knowing Subject. Chicago: University of Chicago Press.

Mills, C. Wright. 1959. The Sociological Imagination. Oxford: Oxford University Press.

Munslow, Alun. 1997. "Editorial." Rethinking History 1(1): 1-20.

Narayan, Kirin. 2012. Alive in the Writing: Crafting Ethnography in the Company of Chekhov. Chicago: University of Chicago Press.

Noël, Patrick-Michel. 2008. "Réfléchir à l'histoire en historien. Vers une connaissance de l'histoire par l'histoire." In Julien. Massicotte et al. (eds.), Actes du 7e Colloque du département d'histoire de l'Université Laval: 165-188. Québec: Artefact.

2012. "Les historiens québécois et la question de l'historicité de leur savoir." Recherches sociographiques 53(1): 11-39. 
2014. Épistémologie, histoire et historiens: considérations conceptuelles, méthodologiques et empiriques autour du discours que les historiens tiennent sur leur savoir. PhD dissertation, Université Laval.

2018. "L'héritage du postmodernisme en histoire : réflexions sur le rapport des historiens à l'exercice épistémologique”, Revue de l'Université de Moncton 48(2): forthcoming.

Noiriel, Gérard. 2005. Sur la "crise" de l'histoire. Paris: Gallimard.

Nora, Pierre (ed.). 1987. Essais d'égo-histoire. Paris: Gallimard.

Novick, Peter. 1988. That Noble Dream: The "Objectivity Question" and the American Historical Profession. New York: Columbia University Press.

Ong, Aihwa. 2006. Neoliberalism as Exception. Durham: Duke University Press.

Paul, Herman. 2011. "Performing History: How Historical Scholarship Is Shaped by Epistemic Virtues." History and Theory 50(1): 1-19. 2014. "What Is a Scholarly Persona? Ten Theses on Virtues, Skills, and Desires," History and Theory 53(3): 348-371.

Pels, Dick. 2003. Unhastening Science: Autonomy and Reflexivity in the Social Theory of Knowledge. Liverpool: Liverpool University Press.

Poirrier, Philippe. 2004. Les Enjeux de l'histoire culturelle. Paris: Seuil.

Polanyi, Michael. 1983. The Tacit Dimension. Chicago: University of Chicago Press.

Prost, Antoine. 1996. Douze leçons sur l'histoire. Paris: Seuil.

Popkin, Jeremy. 2005. History, Historians and Autobiography. Chicago: University of Chicago Press.

Ricoeur, Paul. 2004. Memory, History, Forgetting. Chicago: University of Chicago Press.

Rose, Gillian. 1997. "Situating knowledges: positionality, reflexivities and other tactics." Progress in Human Geography 21(3): 305-320.

Scott, James C. 1998. Seeing Like a State: How Certain Schemes to Improve the Human Condition Have Failed. New Haven: Yale University Press.

Sibum, Otto. 1995. "Reworking the mechanical value of heat: Instruments of precision and gestures of accuracy in early Victorian England." Studies in History and Philosophy of Science Part A 26(1): 73-106.

Simiand, François. 1960. "Méthode historique et Science sociale," Annales. Économies, Sociétés Civilisations 15(1): 83-119.

Sperber, Dan. 1996. Explaining culture: a naturalistic approach. Oxford: Blackwell.

Steedman, Carolyn. 2002. Dust: The Archive and Cultural History. New Brunswick: Rutgers University Press.

Strathern, Marilyn. 2000. "Accountability... and ethnography." In Marilyn 
Strathern (ed.), Audit Cultures: Anthropological studies in accountability, ethics and the academy: 257-304. London: Routledge.

Swedberg, Richard. 2014. The Art of Social Theory. Princeton: Princeton University Press.

Taussig, Karen Sue. 2009. Ordinary Genomes: Science, Citizenship, and Genetic Identities. Durham: Duke University Press.

Taussig, Michael. 1999. Defacement: Public Secrecy and the Labor of the Negative. Stanford, Stanford University Press.

Thuillier, Guy. 2013. La pratique de l'histoire: introduction au métier de l'historien. Paris: Economica.

-2015. Le jeu de l'historien: introduction au métier de l'historien. Paris : Economica.

Traweek, Sharon. 1988. Beamtimes and Lifetimes: the world of high energy physicists. Cambridge, Harvard University Press.

Tucker, Aviezer. 2004. Our Knowledge of the Past: A Philosophy of Historiography. Cambridge: Cambridge University Press.

Verran, Helen. 2001. Science and an African Logic. Chicago: University of Chicago Press.

Veyne, Paul. 2004. Writing History: Essay on Epistemology. Manchester: Manchester University Press.

Waquet, Françoise. 2015. L'ordre matériel du savoir: Comment les savants travaillent : XVIe-XXIe siècles. Paris: CNRS éditions.

White, Hayden. 1973. "The Politics of Contemporary Philosophy of History." Clio 3(1): 35-53.

1978. Tropics of discourse: Essays in Cultural Criticism. Baltimore: Johns Hopkins University Press.

Zammito, John. 2004. A Nice Derangement of Epistemes: Post-positivism in the Study of Science from Quine to Latour. Chicago: University of Chicago Press. 